\title{
Bacterial Community Structure and Diversity of Closely Located Coastal Areas
}

\author{
Md. Nurul Haider ${ }^{1,2}$, Masahiko Nishimura1, Kazuhiro Kogure ${ }^{1}$ \\ ${ }^{1}$ Atmosphere and Ocean Research Institute, The University of Tokyo, Kashiwa, Japan \\ ${ }^{2}$ Faculty of Fisheries, Bangladesh Agricultural University, Mymensingh, Bangladesh \\ Email: *raselmnh@aori.u-tokyo.ac.jp, "raselmnh@yahoo.com
}

Received 4 June 2016; accepted 25 July 2016; published 28 July 2016

Copyright (C) 2016 by authors and Scientific Research Publishing Inc.

This work is licensed under the Creative Commons Attribution International License (CC BY). http://creativecommons.org/licenses/by/4.0/

c) (i) Open Access

\begin{abstract}
Bacterial community structure and diversity of two closely located stations are usually considered similar which can be verified by more intensive investigations using relatively large amount of datasets from the next generation sequencer. This study was conducted to assess the bacterial community structure and diversity between two closely located coastal stations, the port side and the sea side of the Oarai, Ibaraki, Japan from March 2013 to July 2014 using 454 GS Junior sequencer. Two stations underwent similar changes in physicochemical properties but the community structure and diversity was different. The Proteobacteria (the class Alphaproteobacteria, followed by the Gammaproteobacteria) and the Bacteroidetes (the class Flavobacteriia) were two abundant phyla in both the stations. But, the Flavobacteriia was more abundant in the port side, contributed about $26 \%$ to $48 \%$, compared to the sea side (about $12 \%$ to $39 \%$ ). Conversely, the relative abundance of the Gammaproteobacteria was higher on the sea side, about $10 \%$ to $17 \%$, compared to the port side (about $4 \%$ to $12 \%$ ). Among others, the phyla Cyanobacteria, Deferribacteres, Verrucomicrobia and the class Betaproteobacteria were also relatively abundant at the sea side. Because of their dominancy, the class Flavobacteriia and Alphaproteobacteria were further analysed at a lower phylogenetic level and marked differences were observed between the stations. Bacterial biodiversity in terms of the species richness (Chao index) and evenness (inverse Simpson) indicated higher patterns of diversity in the sea side area compared to the port side. Non-metric Multidimensional Scaling fitting with the environmental features (metaMDS), redundancy analysis (RDA) and Bray-Curtis clustering analysis also showed marked differences in bacterial community structure and diversity between the stations. However, some OTUs were commonly found in both the stations in all the sampling periods. So, the bacterial community structure and diversity of the coastal areas are distinguishable even between two closely located sampling points.
\end{abstract}

\footnotetext{
"Corresponding author.
} 


\section{Keywords}

\section{Coastal Bacteria, Community Structure, Diversity, High-Throughput Sequencing, Roche 454}

\section{Introduction}

The community structures of bacteria are considered as one of the most fundamental information in microbial ecology as it provides basic information regarding the environment. Bacterial communities are usually modified by many environmental conditions [1]-[3] and their spatiotemporal changes and biogeographical distributions are of special attention [4]. However, in common practice bacterial community structures are considered similar between two closely located areas of an aquatic environment and treated them as replicate to one another. To verify this concept, more intensive investigations at a relatively finer scale are required which had been hampered due to methodological limitations, mainly the difficulties in culturing prokaryotic cells. Recent developments of molecular techniques, however, considerably overcome this problem by directly obtaining the genetic information without cultivation [5]-[8]. Furthermore, the introduction of the next generation sequencer [NGS] made it possible to obtain by a far large amount of sequencing data within a short period of time and showed the presence of numerous previously unknown sequences or operational taxonomic units (OTUs). These facilities allowed us to assess any similarity or dissimilarity even between two closely located areas at different times of the year.

Microbial habitats are fluctuating widely in coastal environments because of the influences of terrestrial, freshwater and oceanic conditions. Some areas are also affected by anthropogenic activities. Organic matters, nutrients, pollutants and microorganism may be brought into coastal environments depending on the geographical characteristics, season, local weather, currents and so on. Coastal microbial communities consisting of highlyactive and diversified microbes have an important role in alleviating pollution and environmental damage due to nutritional supply from terrestrial sources [9]. Also, the higher levels of bacterial diversity in the coastal estuarine habitats are considered to be causally related to the mixing of bacterial communities from different environments through the act of river influx and tidal exchange [10]. A number of physicochemical parameters significantly influence the bacterial diversity of this brackish water habitat such as temperature, salinity, and dissolved nutrients [11]. Although, the large populations of bacteria are well documented in coastal water research, their variations in terms of community structure and diversity between closer points were not considered well.

The purpose of this study is to assess the similarities or dissimilarities in bacterial community structure and diversity between two coastal areas of Oarai, Ibaraki, Japan at different time scale. The studied stations are located closely, only about one kilometer far from one another. One of them is the Oarai port area (port side), partly bounded by a sea bank, and the other is the Oarai beach area on the open seashore (sea side). We assumed that although the study areas are located closely, their community structure and biodiversity will be different. Because of more influences by both freshwater and marine water, bacterial biodiversity will be higher on the sea side station compare to the port side. As the stations are located closely, sea waters seem to be exchanged between them and thus, the basic physicochemical properties will be similar.

\section{Material and Methods}

\subsection{Sampling Collection}

The seawater samples were collected from two sampling stations, the "port side" (36 30'99"N and 140 $\left.58^{\circ} 46^{\circ} \mathrm{E}\right)$ and "sea side" (36 $31^{\circ} 74^{\prime \prime N}$ and $\left.140^{\circ} 59^{\prime} 20^{\prime \prime} \mathrm{E}\right)$, of the Oarai coastal area of the North Pacific Ocean, Ibaraki prefecture, Japan (Figure 1). Sampling stations are located closely, about $1 \mathrm{~km}$ far from one to another. One of them, the port side, is close to the Oarai port area which is semi-enclosed by a sea bank. The sea side sampling point, one the other hand, is thought to be subjected to the river inflow to some extent because, the Naka River, one of the class-one rivers of Japan, and the Hinuma River flows into the Pacific at the north end of the coastline.

In order to observe the similarities and dissimilarities in bacterial community structure and diversity at different 


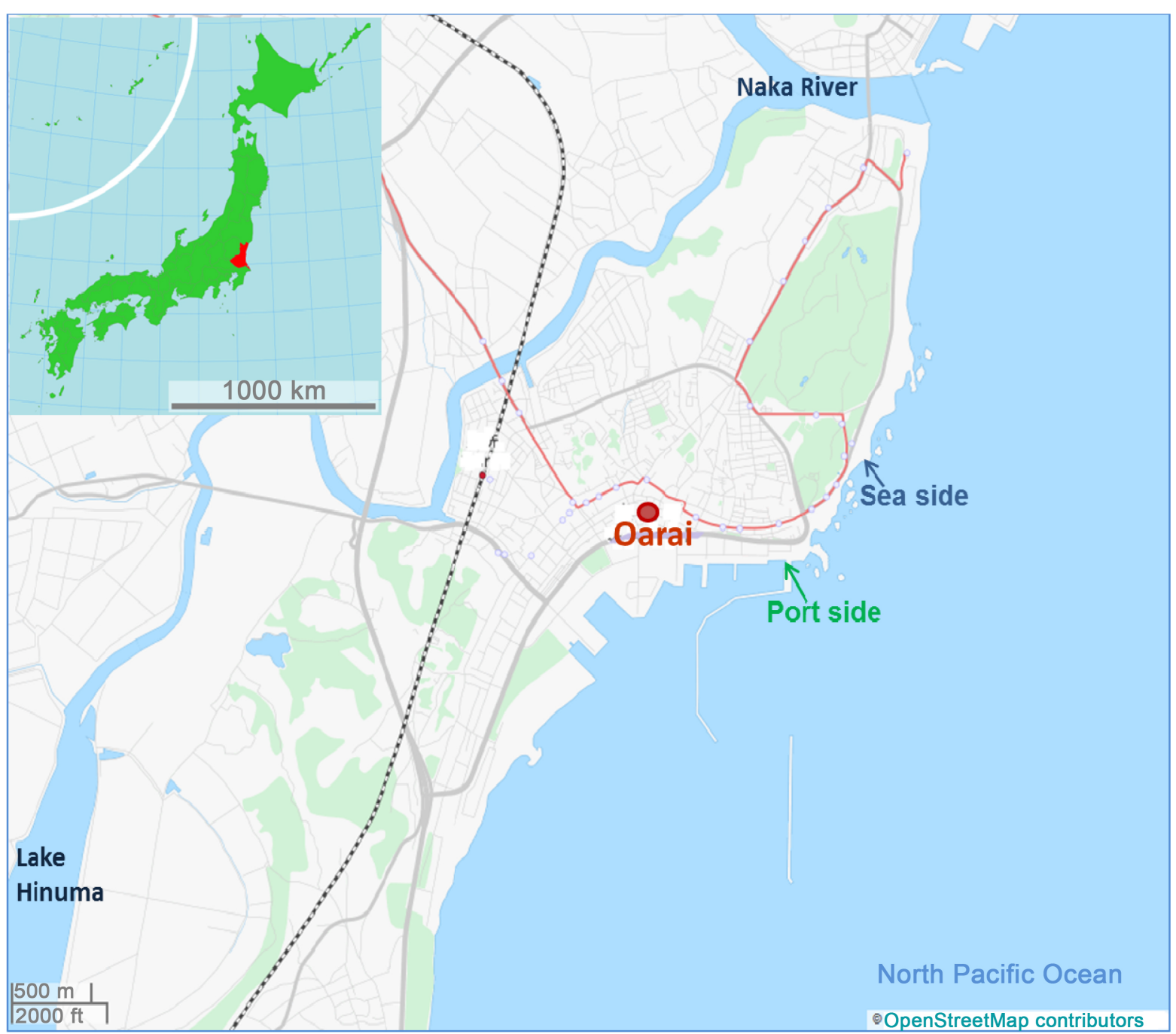

Figure 1. Sampling stations, the port side and the sea side; the inset map area filled with red color is the Ibaraki prefecture and the arrow indicating the position of Oarai.

time scale, water samples were collected in March 2013 (early spring), October 2013 (autumn), February 2014 (winter), April 2014 (spring), and July 2014 (summer). At every sampling, about 5 liters of seawaters were collected in a previously sterilized screw-capped plastic bag and carried back to the laboratory in ice boxes within 2 hours after sampling.

\subsection{Sample Filtrations and Preparation}

About two litres of the seawater sample were filtered through $0.22 \mu \mathrm{m}$ pore sized Sterivex-GP pressure filter unit (Millipore, Billerica, MA, USA) using a peristaltic pump to have the community compositions. The sterivex cartridge filters were immediately kept in sterile bags and stored at $-80^{\circ} \mathrm{C}$ until further processing. The filters in the sterivex units were cut aseptically and placed inside screw tubes just before DNA extraction.

\subsection{Environmental Parameters}

The water temperature was measured at the time of sampling by using a mercurial thermometer. The seawater salinity was determined by a handy refractometer (IS/Mill-E, As One, ATAGO, Japan). The chlorophyll-a dataset with 4-km resolution was obtained from Level-3 MODerate resolution Imaging Spectroradiometer (MODIS) aqua standard-mapped image distributed by the National Aeronautics and Space Administration (NASA) Goddard 
Space Flight Center (oceancolor.gsfc.nasa.gov/cms). Averages of eight consecutive days used to prepare chlorophyll- $a$ illustrated maps for each sampling time using Ocean Data View (ODV) software [12].

\subsection{DNA Extraction and Cleaning}

DNA was extracted from the sterivex filters by combined use of ChargeSwitch Forensic DNA Purification Kits (Invitrogen ${ }^{\mathrm{TM}}$, Carlsbad, USA) and ZircoPrep Mini (FastGene ${ }^{\mathrm{TM}}$, Nippon Genetics Co. Ltd., Bunkyo-ku, Tokyo, Japan) beads beating with a slight modification of the manufacturer's protocol. A MicroSmash (MS-100R, Tomy Medico., Ltd., Tokyo, Japan) was used for beads beating at $5000 \mathrm{rpm}$ and $4^{\circ} \mathrm{C}$ for 30 seconds for each filter under sterile conditions with a great care to avoid contamination. The extracted DNA was also cleaned using NucleoSpin (MACHEREY-NAGEL GmbH \& Co. KG, Neumann-Neander-Str., Düren, Germany) gDNA cleanup kit according to the manufacturer protocol and stored $-30^{\circ} \mathrm{C}$ until amplification.

\subsection{S rDNA Amplification and Pyrosequencing}

The V1-V3 hyper variable regions of 16S rDNA gene were amplified from the extracted DNA templates by polymerase chain reaction (PCR). The 27F with multiplex identifier (MID): 5'-CCATCTCATCCCTGCGTGTCTCCGACTCAGXXXXXXXXXXAGAGTTTGATCMTGGCTCAG-3', where X's represents the sample-specific multiplex identifier-MID [13] was used as the forward primer and the 519R with adaptor: 5'-CCTATCCCCTGTGTG-CCTTGGCAGTCTCAG(GWATTACCGCGGCKGCTG)-3' was used as the reverse primer. Each PCR reactions were carried out in a volume of $20 \mu \mathrm{L}$ in triplicates while the mixture consisted of $2 \mu \mathrm{L}$ DNA template, $13.1 \mu \mathrm{L}$ molecular biological grade double distilled water, $0.6 \mu \mathrm{L}(5 \mu \mathrm{M})$ each primer, $2 \mu \mathrm{L}$ 10X TaKaRa Ex Taq Buffer, $1.6 \mu \mathrm{L}$ TaKaRa dNTP mixture, and $0.1 \mu \mathrm{L}$ TaKaRa Ex Taq HS Polymerase (TaKaRa, Japan). Thermal cycling was carried out for a total of 25 cycles as per the following conditions: initial denaturation at $94^{\circ} \mathrm{C}$ for 4 mins, denaturation at $98^{\circ} \mathrm{C}$ for $10 \mathrm{sec}$, annealing at $55^{\circ} \mathrm{C}$ for $30 \mathrm{sec}$, elongation at $72^{\circ} \mathrm{C}$ for $1 \mathrm{~min}$ and final elongation at $72^{\circ} \mathrm{C}$ for 10 mins. After amplification, the desired length of the 16S rDNA gene was confirmed by agarose gel electrophoresis and any sort of contamination was carefully verified by observing the bands of the triplicates of the same samples. After confirming the desired length, amplified DNA products were purified and normalized using Agencourt AMPure XP (Beckman Coulter INC., USA) according to the guidance of the 454 Sequencing Amplicon Library Preparation Method Manual (GS Junior Titanium Series 2012, Roche, USA). The purified DNA amplicon was then quantified using Quant-iT Picogreen dsDNA Kit (Invitrogen, Carlsbad, USA). The bacterial 16S rDNA gene amplicons were then sequenced using the 454 GS Junior sequencer (Roche, USA) at Atmosphere and Ocean Research Institute (AORI), the University of Tokyo (Kashiwa, Chiba, Japan) according to the manufacturer's protocol for 454 GS Junior Titanium Series.

\subsection{Sequence Analyses}

The open-sourced MOTHUR program [14] was used for subsequent analysis, quality checking and arrangement of the obtained sequences following the guidelines available to the operation manual for the 454

[http://www.mothur.org/wiki/454_SOP]. Initially, the unique sequences were selected and then the similar sequences were clustered and aligned against the SILVA bacterial databases [15]. Then the pre-cluster method [16] was applied to reduce the sequencing errors by screening, filtering, and de-noising. The chimera. uchime command was used for checking and removing the chimeras. The sequences were subsequently classified against the ribosomal 160 database project (RDP) database and the inactive components such as chloroplast, mitochondria etc. organelles affiliated "former" bacterial sequences were removed from our dataset to improve the data quality. The qualified high-quality sequences were then used to generate distance matrix and clustered assigning to operational taxonomic units (OTUs) at $97 \%$ identity level [17]. A representative sequence from every OTU was used for classification by running the MOTHUR program based on the SILVA bacterial databases. To standardize the number of sequences between samples, they were randomly re-sampled to the sample with the fewest reads (2674 reads) using the MOTHUR program based on the OTU files clustered at 0.03 cut-off levels.

The species richness and diversity indices were considered to evaluate the biodiversity and analyse the rarefaction. For the species richness, the Chao1 index [18], and for diversity, the inverse Simpson (Invsimpson) index [19] was calculated using the MOTHUR software at OTU definition at a distance of 0.03 . 


\subsection{Statistical Analyses for Community Structure}

To check the correlations between bacterial communities and environmental factors, nonmetric multidimensional scaling fitting with the environmental features (metaMDS) was carried out based on the relative abundance data of each OTUs. The permutation test was used following the "MASS" [20] and "Vegan" package [21] from R software (R Development Core Team 2012). Redundancy analysis (RDA) was also carried out using the R software with "Vegan" package [21] based on the relative abundance data of each OTUs and environmental information. Toassess the similarities or dissimilarities between the bacterial groups of the two sampling stations, the clustering analysis (Bray-Curtis) test [22] was also performed using the R software with "Vegan" package [21].

\section{Results}

\subsection{Environmental Parameters}

Changes in the water temperature, salinity, and chlorophyll-a values at the two sampling stations are shown in Table 1. Salinity showed similar fluctuation patterns at both stations, with the maximum values, around 35, were obtained in February 2014 and the minimum, around 24, in July 2014 after the rainy season for both the stations. Other features, such as water temperature and water depth were also similar at both the stations.

The chlorophyll- $a$ values obtained from the satellite data were used to prepare chlorophyll- $a$ illustrated maps (Figure 2) for each date of sampling using Ocean Data View (ODV) software. Then the chlorophyll- $a$ values of the sampling locations were obtained from this illustrated maps considering the location (latitude and longitude) of the sampling stations. However, as the sampling stations are closely located, it was not possible to obtain data separately for the two stations (Table 1). The chlorophyll- $a$ values varied from about $2.5 \mu \mathrm{g} \cdot \mathrm{m}^{-3}$ in February to about $5.0 \mu \mathrm{g} \cdot \mathrm{m}^{-3}$ in March. No chlorophyll- $a$ data was obtained during July due to cloudy weather (Table 1 and Figure 2).

\subsection{Bacterial Community Structure Analysis}

After sequencing all the samples a total of 66,609 sequences were obtained which consists of 5249 different types of OTUs. The obtained sequences were analysed for community composition. The composition of the

Table 1. Description of the environmental characteristics of the sampling sites throughout the study periods. The water temperatures and salinity were determined by using a mercurial thermometer and a handy refractometer respectively. Chlorophyll- $a$ data were obtained from the satellite data of NASA's Ocean Color website.

\begin{tabular}{|c|c|c|c|c|c|c|}
\hline \multirow{2}{*}{ Samplings } & \multirow{2}{*}{ Sampling Sites } & \multirow{2}{*}{$\begin{array}{c}\text { Water } \\
\text { Temp. }\left({ }^{\circ} \mathrm{C}\right)\end{array}$} & \multirow{2}{*}{ Salinity $^{*}$} & \multirow{2}{*}{$\begin{array}{l}\text { Water } \\
\text { depth }\end{array}$} & \multicolumn{2}{|c|}{ Chlorophyll-a $\left(\mu \mathrm{g} \cdot \mathrm{m}^{-3}\right)^{* *}$} \\
\hline & & & & & Closest location with data & Obtained values \\
\hline \multirow{2}{*}{ Mar-2013 } & Port Side & 13.5 & 31 & \multirow{2}{*}{ Surface } & \multirow{2}{*}{$\begin{array}{l}36.292^{\circ} \mathrm{N} / \\
140.583^{\circ} \mathrm{E}\end{array}$} & \multirow{2}{*}{4.99} \\
\hline & Sea Side & 13.8 & 35.1 & & & \\
\hline \multirow{2}{*}{ Oct-2013 } & Port Side & 18.8 & 28.8 & \multirow{2}{*}{ Surface } & \multirow{2}{*}{$\begin{array}{l}36.292^{\circ} \mathrm{N} / \\
140.583^{\circ} \mathrm{E}\end{array}$} & \multirow{2}{*}{4.87} \\
\hline & Sea Side & 19.4 & 30.1 & & & \\
\hline \multirow{2}{*}{ Feb-2014 } & Port Side & 8.7 & 35 & \multirow{2}{*}{ Surface } & \multirow{2}{*}{$\begin{array}{l}36.292^{\circ} \mathrm{N} / \\
140.583^{\circ} \mathrm{E}\end{array}$} & \multirow{2}{*}{2.47} \\
\hline & Sea Side & 8.9 & 35.2 & & & \\
\hline \multirow{2}{*}{ Apr-2014 } & Port Side & 13.5 & 31 & \multirow{2}{*}{ Surface } & \multirow{2}{*}{$\begin{array}{l}36.333^{\circ} \mathrm{N} / \\
140.583^{\circ} \mathrm{E}\end{array}$} & \multirow{2}{*}{3.09} \\
\hline & Sea Side & 13.6 & 32 & & & \\
\hline \multirow[b]{2}{*}{ July-2014 } & Port Side & 23.4 & 24.5 & \multirow[b]{2}{*}{ Surface } & \multirow[b]{2}{*}{ No data } & \\
\hline & Sea Side & 21.9 & 24 & & & \\
\hline
\end{tabular}

${ }^{*}$ PSU, practical salinity unit. ${ }^{* *}$ As the sampling stations are located closely, just about $1 \mathrm{~km}$ far from one another, it was not possible to get chlorophyll- $a$ data separately for port side and sea side station rather a single value from the closest available location was noted here for both the stations. 

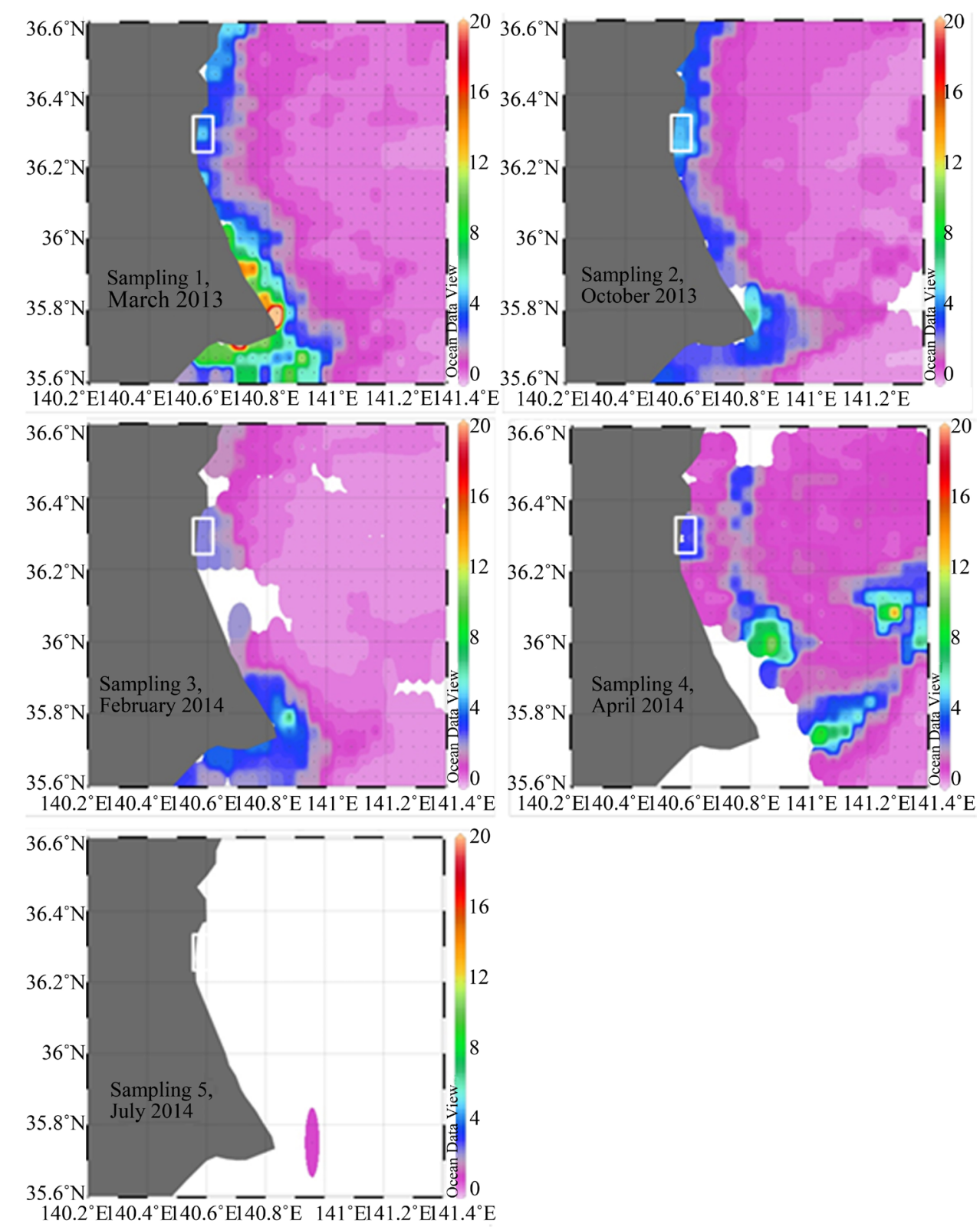

Figure 2. Chlorophyll- $a$ data from satellite at different dates of sampling (8 days average, prepared by using Ocean Data View software). Some areas in the figures kept blank (white) because of unavailability of data due to clouds.

major groups mostly at phylum/class level is presented to Figure 3.

The Phylum Proteobacteria was the most dominant one followed by the Bacteroidetes at almost all the sampling periods regardless of the sampling stations. Among different subgroups of Proteobacteria, the class Alphaproteobacteria was the most abundant one and the class Gammaproteobacteria was the second. In the case of the phylum Bacteroidetes, the class Flavobacteriia was mostly abundant. The relative abundance of the Flavobacteriia was higher in port side while the Gammaproteobacteria in the sea side at almost all the sampling periods. The class Alphaproteobacteria was almost equal or slightly higher in the port side station except April 2014. Among other groups the phylum Cyanobacteria, Verrucomicrobia and the class Betaproteobacteria were higher in abundance to the sea side as compared to the port side. Moreover, the unclassified members were also higher on the sea side. The class Flavobacteriia was most abundant in March, followed by the February at the port side, while the class Alphaproteobacteria in July at both the sampling points. The abundance of the phylum Cyano- 


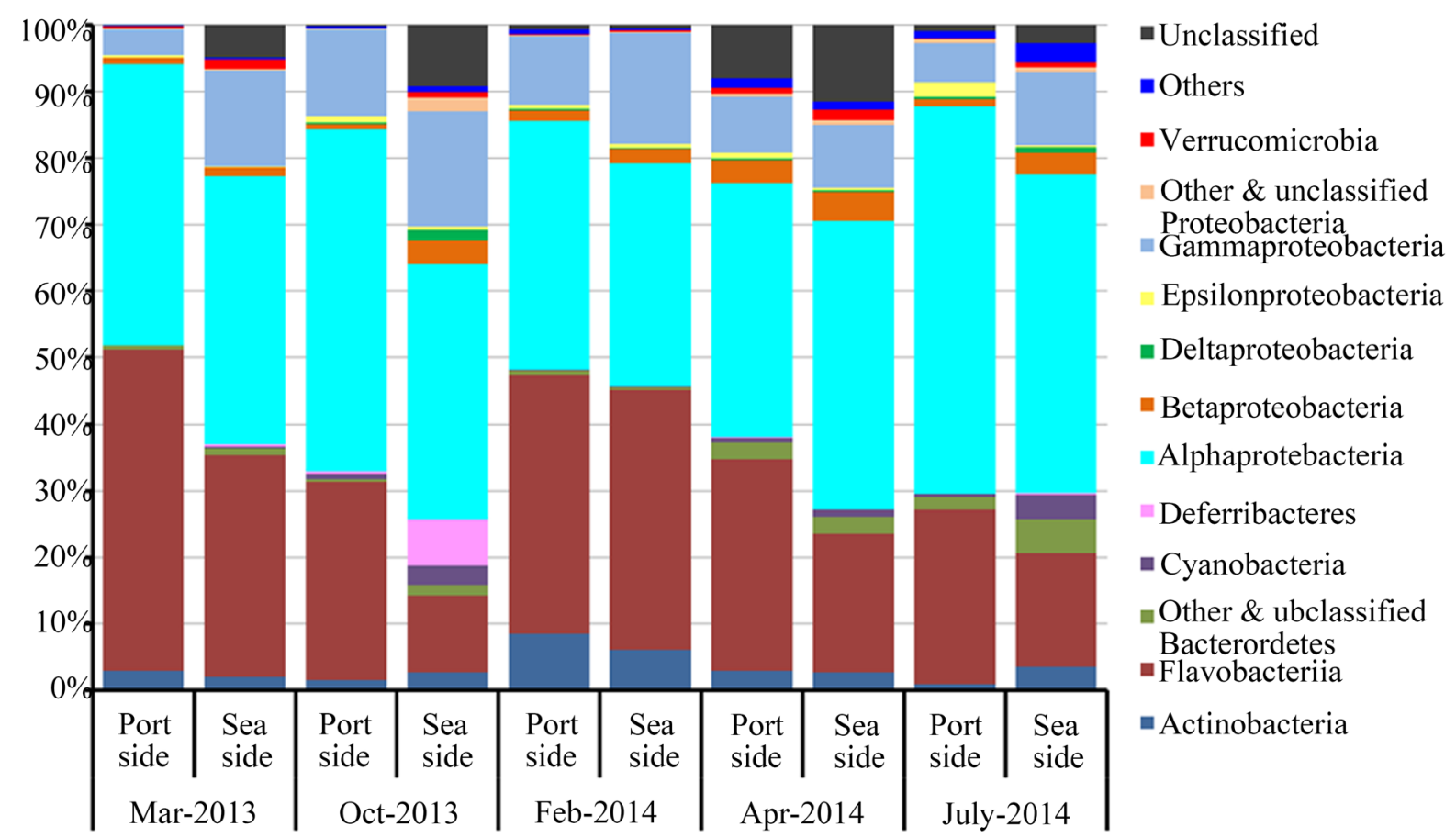

Figure 3. Bacterial community structure of the studied stations at different sampling periods deduced from the 16S rRNA pyrosequencing analysis. The groups “Others” referred to the sum of those phyla did not individually contributed $1 \%$ of the relative abundance in at least one sample and "Unclassified" are the unidentified/unknown members.

bacteria was also relatively higher in July and lower or almost absent in March and February; while the phylum Actinobacteria was more abundant in February. The phylum Deferribacteres was found abundant in October at sea side station (Figure 3).

As the class Flavobacteriia and Alphaproteobacteria were 2 most dominant classes in both the stations throughout study periods, community composition within these classes at family or genus level was also evaluated. In the case of Flavobacteriia, the order Flavobacteriales was the only contributing group (Figure 4). Although, there were differences between the sampling periods, but in general, genera NS3a marine group, Polaribacter, and Winogradskyella of the family Flavobacteriaceae comprised most of the bacterial fractions at port side while the genera Flavobacterium, NS4 marine groups and NS5marine groups of the same family at the sea side station (Figure 4). Analysis of the members within Alphaproteobacteria also showed marked differences between the stations (Figure 5). The maximum contribution to the bacterial community was made by the members of the order Rhodobacterales. The genera Lentibacter, Nereida, Sulfitobacter and unclassified members of the family Rhodobacteraceae was relatively abundant in the port side station while the genus Roseobacter clade, order Rickettsiales and SAR11 contributed significantly in the sea side station. However, there were seasonal variations in their abundance. For example, the genus Sulfitobacter contributed mostly to the samples of March, February, and April while the order SAR11 to the samples of October, April and July (Figure 5).

\subsection{Diversity of Bacterial Communities}

Bacterial biodiversity was evaluated in terms of the species richness and richness-evenness considering the Chao index and inverse Simpson (invSimpson) index, respectively, as was shown in Figure 6. The Chao index values were higher at the sea side in March 2013, October 2013 and July 2014 while at the port side in February 2014 and April 2014. Compared to the port side in almost all the sampling periods except April 2014, Simpson index values were higher at the sea side. It seems reasonable, from these observations, to suppose that more diversified communities were made up in the sea side area. For both the indices, the highest values were observed in April and the lowest in October on the port side. Relatively higher Chao index values were observed in October and July on the sea side, while the lowest was shown in February (Figure 6). The rarefaction curves are showing the relationship between the numbers of obtained sequences and observed OTUs (Supplementary Figure 1A). 


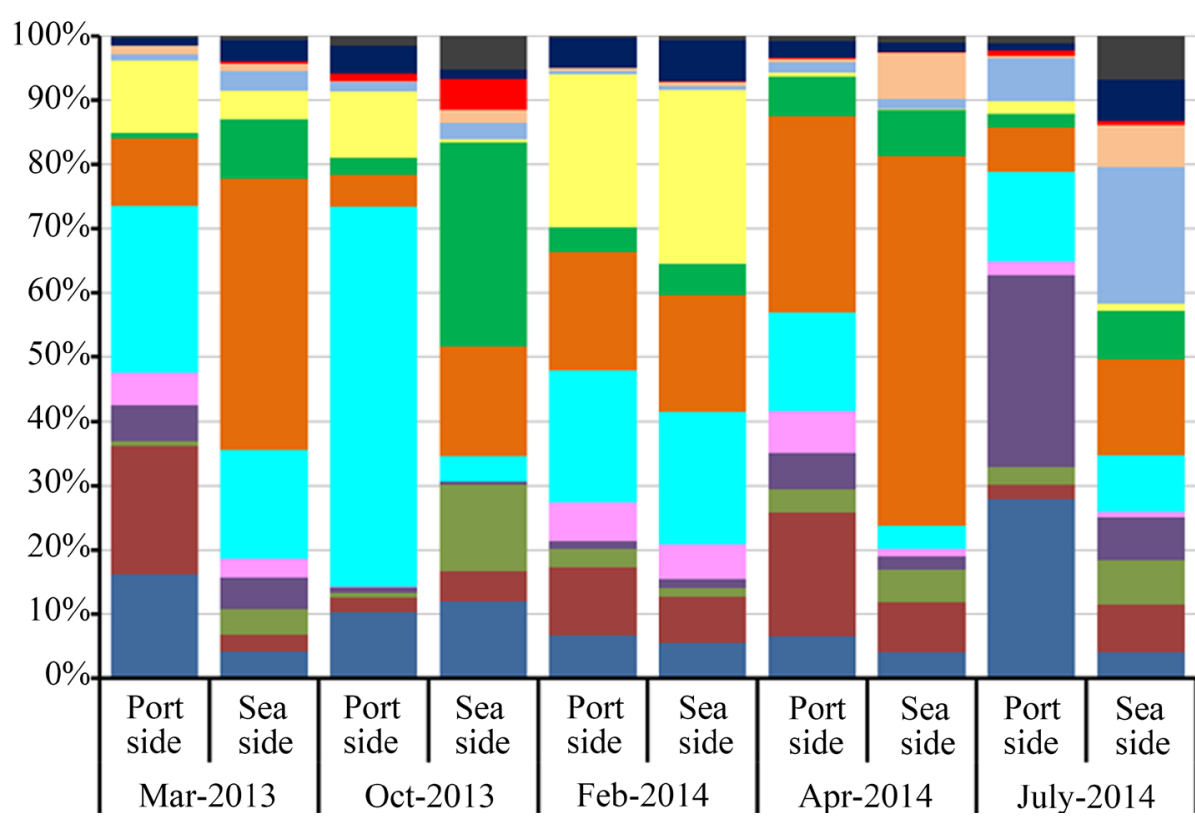

- Fluviicola

(Cryomorphaceae)

- Owenweeksia

(Cryomorphaceae)

- Others and unclassif-

ied Cryomorphaceae

Flavobacteriụm

(Flavobacteriaceae)

Formosa

(Flavobacteriaceae)

NS3 marine group

(Flavobacteriaceae)

- NS4 marine group

(Flavobacteriaceae)

- NS5 marine group

(Flavobacteriaceae)

- Polaribacter

(Flavobacteriaceae)

Ulvibacter

(Flavobacteriaceae)

Winogradskyella

(Flavobacteriaceae)

Other

- Flavobacteriaceae

nclassified

- Flavobacteriaceae

Others and

unclassified

Flavobacteriia

Figure 4. Relative abundance of different members within the class Flavobacteriia showing differences in abundance and composition between the port side and sea side stations at different sampling periods.

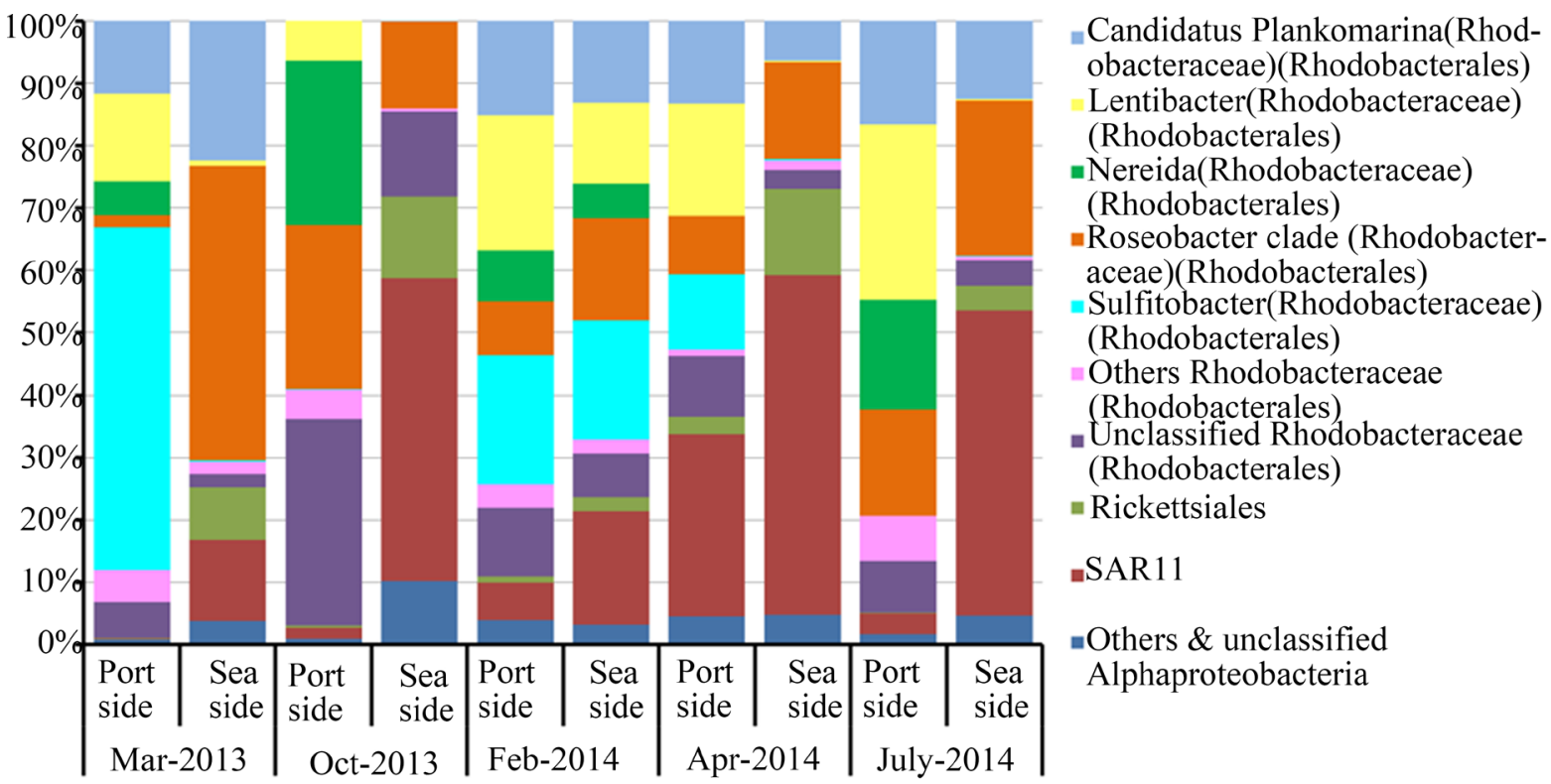

Figure 5. Relative abundance of different members within the class Alphaproteobacteria showing differences in abundance and composition between the port side and sea side stations at different sampling periods.

\subsection{Seasonal Environmental Changes and Bacterial Community Structures of the Locations}

Non-metric Multidimensional Scaling fitting with the environmental features (metaMDS) based on the relative abundance data of the samples and seasonal environmental data was used to categorize bacterial community composition of the studied stations at different sampling periods. The samples were separated according to the sampling periods $\left(r^{2}=0.63\right.$ and $P=0.1$, based on 1000 permutations) as well as according to the stations ( $r^{2}=$ 0.22 and $P=0.17$, based on 1000 permutations); the community composition was similar between the stations at February (Figure 7). 

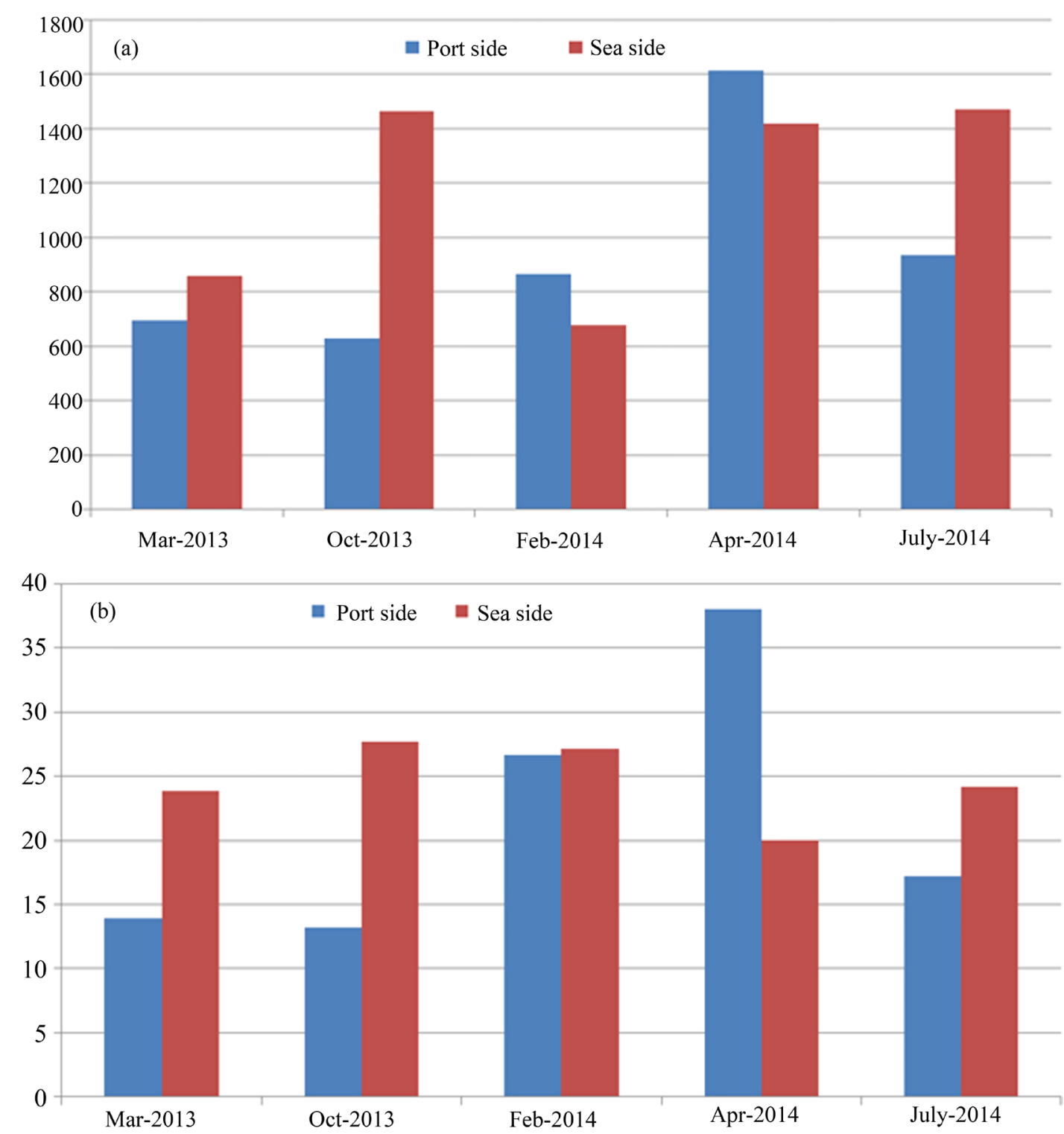

Figure 6. Changes in (a): Chao index and (b): inverse-Simpson index of the studied stations indicating the biodiversity in terms of richness and richness-evenness at various sampling periods.

The association between the bacterial community structure and environmental factors was examined by RDA. In Figure 8, the samples are plotted on a sample-to-sample basis, with respect to stations $\left(r^{2}=0.3\right.$ and $P=0.02$, based on 1000 permutations) and season $\left(r^{2}=0.5\right.$ and $P=0.4$, based on 1000 permutations). The water temperature $\left(r^{2}=0.08\right.$ and $P=0.7$, based on 1000 permutations) and salinity $\left(r^{2}=0.1\right.$ and $P=0.6$, based on 1000 permutations) had no significant influence in clustering (Figure 8).

We performed a Bray-Curtis clustering analysis based on the bacterial relative abundance data at phylogenetic level. Samples were aligned according to degrees of similarity in community composition on a sample-tosample basis (Figure 9). However, the April sample of the port side station was aligned next to the sea side clade, whilst the February sample of the sea side was aligned next to the port side clade. This indicates that there were similarities in bacterial community composition among the samples of the February and April (Figure 9).

\subsection{Analyses of the Common OTUs across Sampling Stations and Seasons}

About $20.92 \%$ to $30.72 \%$ of the OTUs were common in the port side station and about $7.25 \%$ to $31.53 \%$ in the 


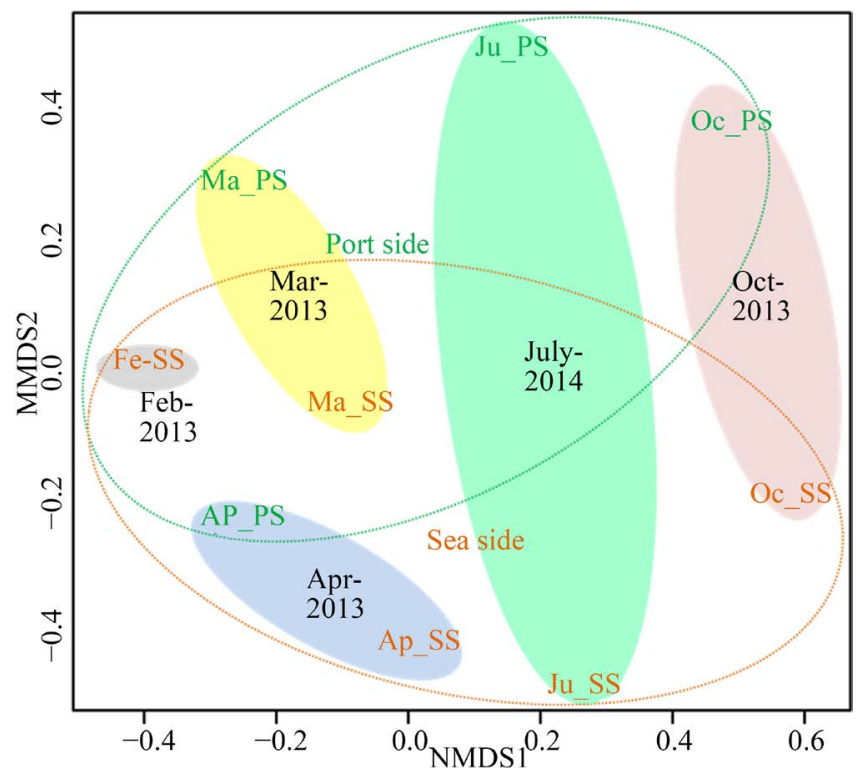

Figure 7. Non-metric Multidimensional Scaling fitting with the environmental features (metaMDS) showing clustering according to the sampling periods and stations. The first and the second part of the sample IDs' are expressing the sampling periods $(\mathrm{Ma}=$ March, Oc = October, Fe = February, Ap = April and Ju = July), and the sampling stations (PS = port side, SS = sea side) respectively. Clustering of two samples closely meaning they are relatively similar in composition.

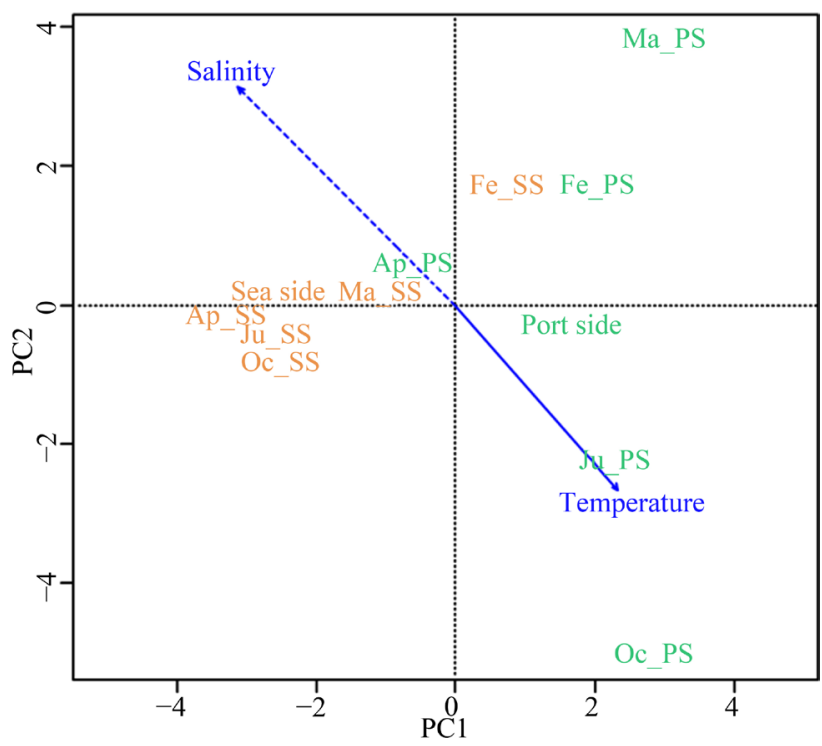

Figure 8. Redundancy analysis (RDA) of the samples showed the clustering of the samples. The abbreviations are same as Figure 7.

sea side station between different sampling periods (Table 2). The percentages of common OTUs shared between March and October, October and February, February and April, and April and July were 6.95, 6.88, 10.20, and 5.79 respectively at the port side station while $7.63,5.12,8.25$, and 7.90 respectively for the sea side station (Table 3). The overall observations showed that bacterial community composition was fluctuated highly between two consecutive sampling periods and the community composition was also dissimilar between the stations at most of the sampling periods (Table 2 and Table 3). 


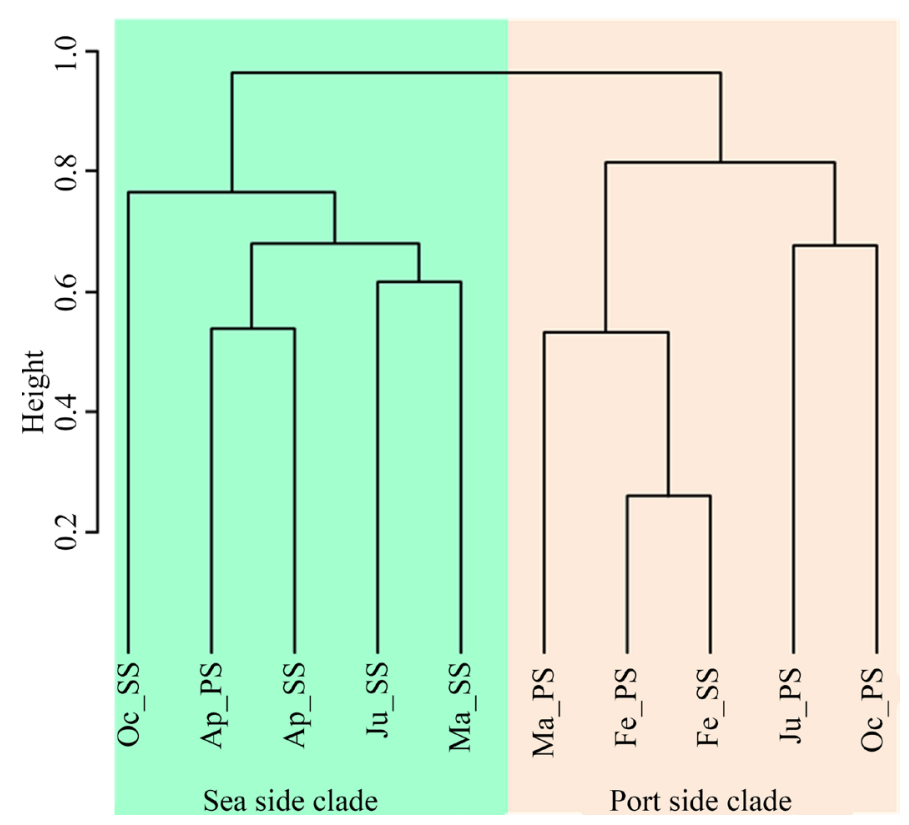

Figure 9. Clustering analysis (Bray-Curtis) showing similarities or dissimilarities in bacterial community composition between the stations. The abbreviations are same as Figure 7. Samples are arranged into two major clades according to the stations. However, the April sample of the port side arranged with the April sample of the sea side in sea side clade while February sample of the sea side arranged with the February sample of the port side in port side clade indicating their compositional similarities.

Table 2. Percentage of common OTUs between the port side and sea side station in different periods of sampling. The percentage was calculated after counting the total number of OTUs appeared at each station as well as among the stations for every sampling period.

\begin{tabular}{|c|c|c|c|c|c|c|c|c|c|c|}
\hline & \multicolumn{2}{|c|}{ Mar-2013 } & \multicolumn{2}{|c|}{ Oct-2013 } & \multicolumn{2}{|c|}{ Feb-2014 } & \multicolumn{2}{|c|}{ Apr-2014 } & \multicolumn{2}{|c|}{ July-2014 } \\
\hline & $\begin{array}{l}\text { Port } \\
\text { side }\end{array}$ & Sea side & Port side & $\begin{array}{l}\text { Sea } \\
\text { side }\end{array}$ & Port side & $\begin{array}{l}\text { Sea } \\
\text { side }\end{array}$ & Port side & $\begin{array}{l}\text { Sea } \\
\text { side }\end{array}$ & $\begin{array}{l}\text { Port } \\
\text { side }\end{array}$ & $\begin{array}{l}\text { Sea } \\
\text { side }\end{array}$ \\
\hline $\begin{array}{c}\text { Total OTUs } \\
\text { observed }\end{array}$ & 375 & 468 & 332 & 985 & 756 & 574 & 918 & 817 & 360 & 1489 \\
\hline $\begin{array}{c}\text { Number of } \\
\text { common OTUs }\end{array}$ & \multicolumn{2}{|c|}{92} & \multicolumn{2}{|l|}{102} & \multicolumn{2}{|c|}{181} & \multicolumn{2}{|c|}{192} & \multicolumn{2}{|c|}{108} \\
\hline $\begin{array}{l}\text { Percentage of } \\
\text { common OTUs }\end{array}$ & 24.53 & 19.66 & 30.72 & 10.36 & 23.94 & 31.53 & 20.92 & 23.50 & 30.00 & 7.25 \\
\hline
\end{tabular}

Table 3. Percentage of common OTUs between two consecutive sampling periods at port side and sea side station in order to evaluate the degree of fluctuations between two sampling periods at OTUs level. The percentage was calculated after counting the total number of OTUs appeared at each sampling periods as well as among two consecutive sampling periods.

\begin{tabular}{|c|c|c|c|c|c|c|c|c|}
\hline & \multicolumn{2}{|c|}{ Mar-2013 vs Oct-2013 } & \multicolumn{2}{|c|}{ Oct-2013 vs Feb-2014 } & \multicolumn{2}{|c|}{ Feb-2014 vs Apr-2014 } & \multicolumn{2}{|c|}{$\begin{array}{l}\text { Apr-2014 vs } \\
\text { July-2014 }\end{array}$} \\
\hline & Port side & Sea side & Port side & Sea side & Port side & Sea side & Port side & $\begin{array}{l}\text { Sea } \\
\text { side }\end{array}$ \\
\hline $\begin{array}{c}\text { Total number of OTUs } \\
\text { observed }\end{array}$ & 662 & 1350 & 1018 & 1483 & 1519 & 1285 & 1208 & 2138 \\
\hline $\begin{array}{c}\text { Number of common } \\
\text { OTUs between the } \\
\text { seasons }\end{array}$ & 46 & 103 & 70 & 76 & 155 & 106 & 70 & 169 \\
\hline $\begin{array}{c}\text { Percentage of common } \\
\text { OTUs }\end{array}$ & 6.95 & 7.63 & 6.88 & 5.12 & 10.20 & 8.25 & 5.79 & 7.90 \\
\hline
\end{tabular}


Only 14 OTUs out of $5249(0.27 \%)$ was found common throughout the study regardless of the sampling periods and stations. However, their contribution to the total abundance was $10.7 \%$ in July to $27.36 \%$ in April on the port side station while $24.46 \%$ in October to $48.31 \%$ in March on the sea side station (Figure 10). Bacterial groups of these common OTUs were Candidatus Actinomarina (Acidimicrobiales) of phylum Actinobacteria; Fluviicola, NS4 marine group, NS5 marine group (2 OTUs), Owenweeksia and Polaribacter (2 OTUs) (Flavobacteriales) of phylum Bacteroidetes; Roseobacter clade (2 OTUs) (Rhodobacteriales) and unclassified SAR11 of Alphaproteobacteria; unclassified Alteromonadales and SAR86 (Oceanospirillales) of Gammaproteobacteria; and 12up (Rhodocyclales) of Betaproteobacteria (Figure 10).

\section{Discussions}

The introduction and use of the next generation sequencer [NGS] made it possible to obtain numerous previously unknown sequences or operational taxonomic units (OTUs) that can be used to verify and assess the bacterial community structure at a relatively finer and intensive scale. This study was conducted to evaluate the similarities or dissimilarities in bacterial community structure and diversity between two closely located coastal areas of Oarai, Ibaraki, Japan at different time scale. Bacterial community structure was retrieved by obtaining high-throughput sequencing data using Roche 454 sequencer. The results indicated that two sampling stations underwent a similar change in physicochemical properties but the community structure and diversity was dissimilar between the stations. The class Alphaproteobacteria followed by the class Gammaproteobacteria of the phylum Proteobacteria and the class Flavobacteriia of the phylum Bacteroidetes were mostly abundant but the relative abundance of Flavobacteriia was higher atthe port side and Gammaproteobacteria at the sea side throughout the study period. Among others, the phyla Cyanobacteria, Deferribacteres, Verrucomicrobia and the class Betaproteobacteria were also relatively abundant at the sea side. It was found that the relative abundance of different bacterial groups was fluctuated markedly across time due to seasonal influences and there also were marked differences between the stations at almost all the sampling periods. Bacterial biodiversity in terms of the species richness (Chao index) and evenness (inverse Simpson) indicated high levels and patterns of diversity in the sea side area compared to those in the port side. Non-metric Multidimensional Scaling fitting with the environmental features (metaMDS), RDA and Bray-Curtis clustering analysis also showed marked differences in the

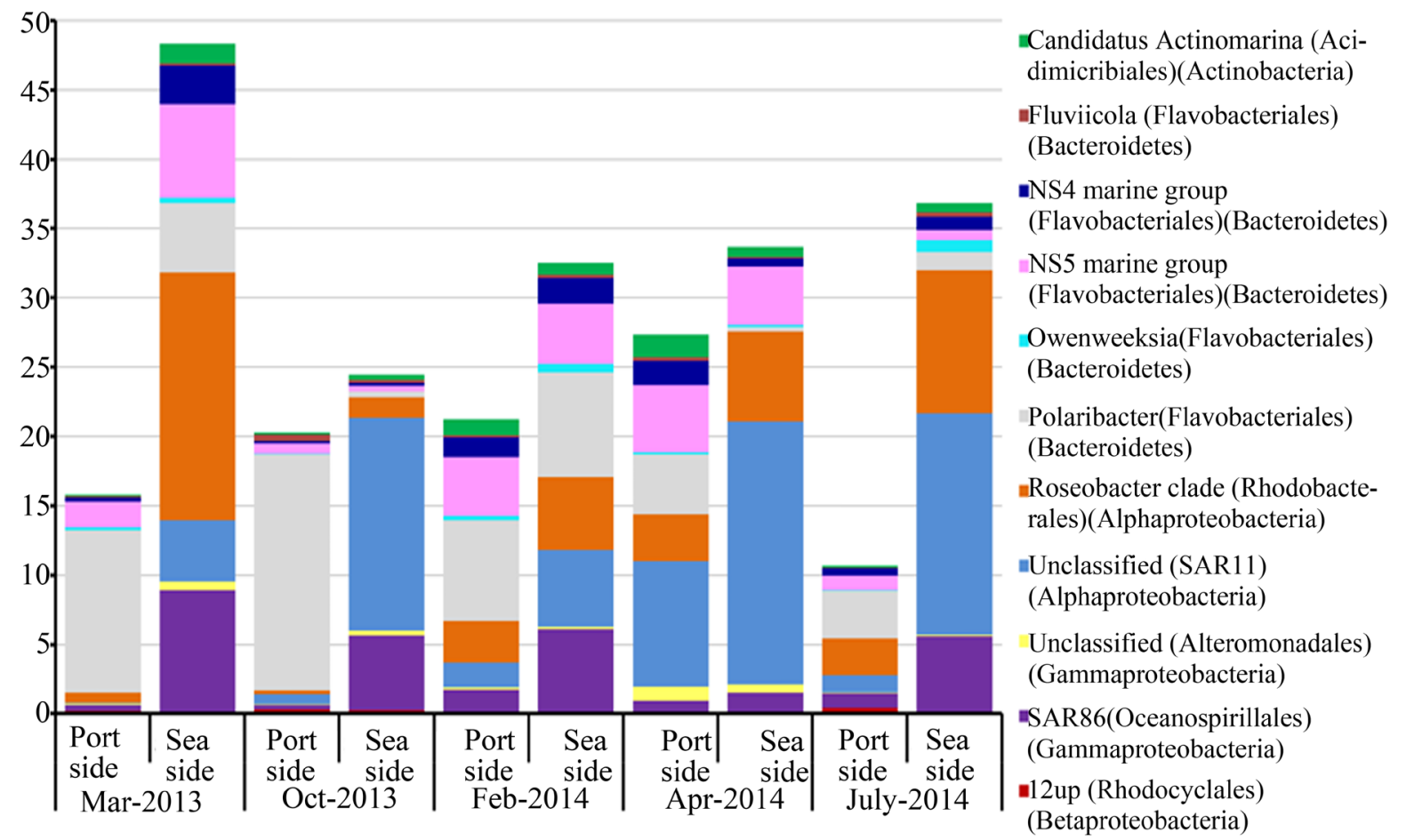

Figure 10. Relative abundance of the bacterial groups of the common OTUs, those were found common at the entire study period regardless of the stations and sampling periods. 
bacterial community structure and biodiversity between the sampling stations. However, some OTUs were commonly found in both the stations in all the sampling periods.

Previous studies suggested that the phylum Proteobacteria was found everywhere as an abundant one. Among different classes of the Proteobacteria, the classes Alphaproteobacteria (mostly SAR11), followed by the Gammaproteobacteria are abundant in marine waters [23]-[26]; while the class Betaproteobacteria is abundant in freshwater habitats [8] [27]-[29]. The phylum Bacteroidetes is also dominant in some freshwater and marine water habitats [27] [29]-[31]. Our results are consistent with those published findings. The higher relative abundance of the phylum Verrucomicrobia at the sea side point may be because they predominate in shallow brackish wasters compared to open oceans [32]. The higher abundance of the phylum Cyanobacteria of July's sampling agreed with the concept that the growth rate of Cyanobacteria is usually higher at high water temperature during the summer season [33]-[35]. The relative abundances of the class Betaproteobacteria were higher at the sea side station, may be because this station is influenced by riverine communities (and so terrestrial communities as well) of the Naka River [36] [37] (Figure 1).

Further analyses of the community composition within the classes Flavobacteriia and Alphaproteobacteria showed marked differences between the studied stations. Within the class Flavobacteriia, the genera NS3a marine group, Polaribacter, and Winogradskyella of the family Flavobacteriaceae comprised most of the bacterial fractions on port side while the genera Flavobacterium, NS4 marine groups and NS5marine groups of the same family at the sea side station (Figure 4). Korlević et al. 2015 [35] reported that pyrotags related to the order Flavobacteriales were abundant, with high frequencies of clades NS2b, NS4, and NS5, which is consistent with our results. The genus Polaribacter was first isolated from a polar marine environment [38], however, it was also isolated from coastal areas of Japan [39] [40]. The genus Winogradskyella was isolated from an alga collected from the Sea of Japan [41] [42] while the members of genus Flavobacterium are widely distributed [43]. Among different members within Alphaproteobacteria, the genera Lentibacter, Nereida, Sulfitobacter and unclassified members of the family Rhodobacteraceae was relatively abundant in the port side station while the Roseobacter clade, order Rickettsiales and SAR11 in the sea side station (Figure 5). Previous reports showed that the marine Rhodobacterales is widespread the members of marine Roseobacter clade formed the most common and dominant surface-colonizing bacterial group [44] [45]. The members of the genus Sulfitobacter are widely distributed in coastal and open ocean environments [46] [47], where they may play an important role in organic sulfur cycling. The type species of the genus Lentibacter was isolated from seawater samples in the coastal region of Qingdao, China, during a massive green algae bloom [48], indicating that this genus has an affinity to eutrophic waters that are present at port side, observed during samplings. Information on the genus $\mathrm{Ne}$ reidain marine environments is very limited [49], but theSAR11 is a typical dominant group in the oceanic surface environment among other orders of Alphaproteobacteria [25] [29] [50]-[52]. Previous reports indicated that these available members of the class Flavobacteriia and Alphaproteobacteria are common in the coastal marine environments, consistent with our findings.

The bacterial diversity at the sea side station was higher than that of the port side station; and within port side station, diversity was higher in April while within sea side station in October (Figure 6). Cury et al. 2011 [53] and Rodrigues et al. 2013 [54] reported that anthropogenic activities negatively influence the bacterial diversity in forest soil and coastal environments respectively, explaining the reason why the bacterial diversity at the port side was less than that of the sea side. Less pollution and better water quality i.e. better ecological condition of the coastal environment also supports higher bacterial diversity [55]. Moreover, introduction and mixing of an exogenous bacterial group from river input may also affect the bacterial diversity in the sea side samples. A number of physical (especially temperature), chemical (salinity, nutrients, oxygen concentration, pollution, etc.), and biological (predation, competition, plankton bloom) factors influence the bacterial diversity in coastal areas [11] [34] [56] [57]. Further consideration of specific environmental factors and investigation of their seasonal changes are required to explain the higher diversity in April at port side and in October at the sea side.

\section{Conclusion}

In conclusion, bacterial community structures and diversity were investigated by seasonal samplings at two closely located coastal stations. Although the community was mostly dominated by the phyla Proteobacteria and Bacteroidetes, there were variations in their relative abundance between the sampling stations and the periods of samplings. The overall observations also indicated that the bacterial communities in the sea side area grow in diversity compared to that in the port side area. So, bacterial community structure and diversity of the coastal 
areas are distinguishable even between two closely located sampling points.

\section{References}

[1] Ruan, Q., Dutta, D., Schwalbach, M.S., Steele, J.A., Fuhrman, J.A. and Sun, F. (2006) Local Similarity Analysis Reveals Unique Associations among Marine Bacterioplankton Species and Environmental Factors. Bioinformatics, 22, 2532-2538. http://dx.doi.org/10.1093/bioinformatics/btl417

[2] Gilbert, J.A., Field, D., Swift, P., Newbold, L., Oliver, A., Smyth, T., Somerfield, P.J., Huse, S. and Joint, I. (2009) The Seasonal Structure of Microbial Communities in the Western English Channel. Environmental Microbiology, 11, 3132-3139. http://dx.doi.org/10.1111/j.1462-2920.2009.02017.x

[3] Gilbert, J.A., Steele, J.A., Caporaso, J.G., Steinbrück, L., Reeder, J., et al. (2012) Defining Seasonal Marine Microbial Community Dynamics. The ISME Journal, 6, 298-308. http://dx.doi.org/10.1038/ismej.2011.107

[4] Treusch, A.H., Vergin, K.L., Finlay, L.A., Donatz, M.G., Burton, R.M., Carlson, C.A. and Giovannoni, S.J. (2009) Seasonality and Vertical Structure of Microbial Communities in an Ocean Gyre. The ISME Journal, 3, 1148-1163. http://dx.doi.org/10.1038/ismej.2009.60

[5] DeLong, E.F., Franks, D.G. and Alldredge, A.L. (1993) Phylogenetic Diversity of Aggregate-Attached vs Free-Living Marine Bacterial Assemblages. Limnology and Oceanography, 38, 924-934. http://dx.doi.org/10.4319/lo.1993.38.5.0924

[6] Giovannoni, S.J., Mullins, T.D. and Field, K.G. (1995) Microbial Diversity in Oceanic Systems: rRNA Approaches to the Study of Unculturable Microbes. NATO Advanced Science Institutes Series G, 38, 217-248. In: Joint, I., Ed., Molecular Ecology of Aquatic Microbes, Springer-Verlag Berlin Heidelberg. http://dx.doi.org/10.1007/978-3-642-79923-5_13

[7] Acinas, S.G., Rodríguez-Valera, F. and Pedrós-Alió, C. (1997) Spatial and Temporal Variation in Marine Bacterioplankton Diversity as Shown by RFLP Finger-Printing of PCR Amplified 16S rDNA. FEMS Microbiology Ecology, 24, 27-40. http://dx.doi.org/10.1111/j.1574-6941.1997.tb00420.x

[8] Hiorns, W.D., Methe, B.A., Nierzwicki-Bauer, S.A. and Zehr, J.P. (1997) Bacterial Diversity in Adirondack Mountain Lakes as Revealed by 16S rRNAgene Sequences. Applied and Environmental Microbiology, 63, 2957-2960.

[9] Danovaro, R. and Pusceddu, A. (2007) Biodiversity and Ecosystem Functioning in Coastal Lagoons: Does Microbial diversity Play Any Role? Estuarine, Coastal and Shelf Science, 75, 4-12. http://dx.doi.org/10.1016/j.ecss.2007.02.030

[10] Crump, B.C., Armbrust, E.V. and Baross, J.A. (1999) Phylogenetic Analysis of Particle-Attached and Free-Living Bacterial Communities in the Columbia River, Its Estuary, and the Adjacent Coastal Ocean. Applied and Environmental Microbiology, 65, 3192-3204.

[11] Andersson, A.F., Riemann, L. and Bertilsson, S. (2010) Pyrosequencing Reveals Contrasting Seasonal Dynamics of Taxa within Baltic Sea Bacterioplankton Communities. The ISME Journal, 4, 171-181. http://dx.doi.org/10.1038/ismej.2009.108

[12] Schlitzer, R. (2014) Ocean Data View. http://odv.awi.de

[13] Kim, M., Morrison, M. and Yu, Z. (2011) Evaluation of Different Partial 16S rRNA Gene Sequence Regions for Phylogenetic Analysis of Microbiomes. Journal of Microbiological Methods, 84, 81-87. http://dx.doi.org/10.1016/j.mimet.2010.10.020

[14] Schloss, P.D., Westcott, S.L., Ryabin, T., Hall, J.R., Hartmann, M., et al. (2009) Introducing Mothur: Open-Source, Platform-Independent, Community-Supported Software for Describing and Comparing Microbial Communities. Applied and Environmental Microbiology, 75, 7537-7541. http://dx.doi.org/10.1128/AEM.01541-09

[15] Pruesse, E., Quast, C., Knittel, K., Fuchs, B.M., Ludwig, W., Peplies, J. and Glöckner, F.O. (2007) SILVA: A Comprehensive Online Resource for Quality Checked and Aligned Ribosomal RNA Sequence Data Compatible with ARB. Nucleic Acids Research, 35, 7188-7196. http://dx.doi.org/10.1093/nar/gkm864

[16] Huse, S.M., Welch, D.M., Morrison, H.G. and Sogin, M.L. (2010) Ironing out the Wrinkles in the Rare Biosphere through Improved OTU Clustering. Environmental Microbiology, 12, 1889-1898. http://dx.doi.org/10.1111/j.1462-2920.2010.02193.x

[17] Schloss, P.D. and Westcott, S.L. (2011) Assessing and Improving Methods Used in Operational Taxonomic UnitBased Approaches for 16S rRNA Gene Sequence Analysis. Applied and Environmental Microbiology, 77, 3219-3226. http://dx.doi.org/10.1128/AEM.02810-10

[18] Chao, A., Chazdon, R.L., Colwell, R.K. and Shen, T.J. (2005) A New Statistical Approach for Assessing Similarity of Species Composition with Incidence and Abundance Data. Ecology Letters, 8, 148-159. http://dx.doi.org/10.1111/j.1461-0248.2004.00707.x

[19] Simpson, E.H. (1949) Measurement of Diversity. Nature, 163, 688-688. http://dx.doi.org/10.1038/163688a0 
[20] Venables, W.N. and Ripley, B.D. (2002) Modern Applied Statistics with S. 2nd Edition, Springer, New York. http://dx.doi.org/10.1007/978-0-387-21706-2

[21] Oksanen, J. (2015) Multivariate Analysis of Ecological Communities in R: Vegan Tutorial. http://cc.oulu.fi/ jarioksa/opetus/metodi/vegantutor.pdf

[22] Bray, J.R. and Curtis, J.T. (1957) An Ordination of Upland Forest Communities of Southern Wisconsin. Ecological Monographs, 27, 325-349. http://dx.doi.org/10.2307/1942268

[23] Fuhrman, J.A. and Davis, A.A. (1997) Wide Spread Archaea and Novel Bacteria from the Deep sea as Shown by $16 \mathrm{~S}$ rRNA Gene Sequences. Marine Ecology Progress Series, 150, 275-285. http://dx.doi.org/10.3354/meps150275

[24] Lopez-Garcia, P., Lopez-Lopez, A., Moreira, D. and Rodriguez-Valera, F. (2001) Diversity of Free-Living Prokaryotes from a Deep-Sea Site at the Antarctic Polar Front. FEMS Microbiology Ecology, 36, 193-202. http://dx.doi.org/10.1016/S0168-6496(01)00133-7

[25] DeLong, E.F., Preston, C.M., Mincer, T., Rich, V., Hallam, S.J., et al. (2006) Community Genomics among Stratified Microbial Assemblages in the Ocean’s Interior. Science, 311, 496-503. http://dx.doi.org/10.1126/science.1120250

[26] Pham, V.D., Konstantinidis, K.T., Palden, T. and DeLong, E.F. (2008) Phylogenetic Analyses of Ribosomal DNAContaining Bacterioplankton Genome Fragments from a $4000 \mathrm{~m}$ Vertical Profile in the North Pacific Subtropical Gyre. Environmental Microbiology, 10, 2313-2330. http://dx.doi.org/10.1111/j.1462-2920.2008.01657.x

[27] Glöckner, F.O., Fuchs, B.M. and Amann, R. (1999) Bacterioplankton Compositions of Lakes and Oceans: A First Comparison Based on Fluorescence in Situ Hybridization. Applied and Environmental Microbiology, 65, 3721-3726.

[28] Kirchman, D.L., Dittel, A.I., Malmstrom, R.R. and Cottrell, M.T. (2005) Biogeography of Major Bacterial Groups in the Delaware Estuary. Limnology and Oceanography, 50, 1697-1706. http://dx.doi.org/10.4319/lo.2005.50.5.1697

[29] Kirchman, D.L. (2012) Processes in Microbial Ecology. Oxford University Press Inc., New York.

[30] Kirchman, D.L. (2002) The Ecology of Cytophaga-Flavobacteria in Aquatic Environments. FEMS Microbiology Ecology, 39, 91-100. http://dx.doi.org/10.1016/s0168-6496(01)00206-9

[31] Amaral-Zettler, L., Artigas, L.F., Baross, J., Bharathi, P.A.L., Boetiuset, A., et al. (2010) A Global Census of Marine Microbes. In: McIntyre, A.D., Ed., Life in the World's Oceans: Diversity, Distribution, and Abundance, WileyBlackwell Oxford, Oxford, 221-245. http://dx.doi.org/10.1002/9781444325508.ch12

[32] Freitas, S., Hatosy, S., Fuhrman, J.A., Huse, S.M., Welch, D.B.M., Sogin, M.L. and Martiny, A.C. (2012) Global Distribution and Diversity of Marine Verrucomicrobia. The ISME Journal, 6, 1499-1505. http://dx.doi.org/10.1038/ismej.2012.3

[33] Konopka, A. and Brock, T.D. (1978) Effect of Temperature on Blue-Green Algae (Cyanobacteria) in Lake Mendota. Applied and Environmental Microbiology, 36, 572-576.

[34] Du, J., Xiao, K., Li, L., Ding, X., Liu, H., Lu, Y. and Zhou, S. (2013) Temporal and Spatial Diversity of Bacterial Communities in Coastal Waters of the South China Sea. PLoS ONE, 8, e66968. http://dx.doi.org/10.1371/journal.pone.0066968

[35] Korlević, M., Ristova, P.P., Garić, R., Amann, R. and Orlić, S. (2015) Bacterial Diversity in the South Adriatic Sea during a Strong, Deep Winter Convection Year. Applied and Environmental Microbiology, 81, 1715-1726. http://dx.doi.org/10.1128/AEM.03410-14

[36] Matsu-ura, T., Uda, T., Kumada, T. and Sumiya, M. (2010) Sand Accumulation in Wave-Shelter Zone of Oharai Port and Change in Grain Size of Seabed Materials on Nearby Coast. The 32nd International Conference on Coastal Engineering, 63, 1-11.

[37] Uda, T. (2010) Impacts on Sandy Beach and Habitat of Japanese Hard Clams Due to Construction of Port Breakwater. International Symposium on Integrated Coastal Management for Marine Biodiversity, in Asia Collective Abstracts B-1, Kyoto, 14-15 January 2010, 28-34.

[38] Gosink, J.J., Woese, C.R. and Staley, J.T. (1998) Polaribacter gen. nov., with Three New Species, $P$. irgensii sp. nov., $P$. franzmannii sp. nov. and P. filamentus sp. nov., Gas Vacuolate Polar Marine Bacteria of the Cytophaga-FlavobacteriumBacteroides Group and Reclassification of "Flectobacillus glomeratus" as Polaribacter glomeratus Comb. nov. International Journal of Systematic Bacteriology, 48, 223-235. http://dx.doi.org/10.1099/00207713-48-1-223

[39] Fukui, Y., Abe, M., Kobayashi, M., Saito, H., Oikawa, H., Yano, Y. and Satomi, M. (2013) Polaribacter porphyrae sp. nov., Isolated from the Red Alga Porphyra yezoensis, and Emended Descriptions of the Genus Polaribacter and Two Polaribacter Species. International Journal of Systematic and Evolutionary Microbiology, 63, 1665-1672. http://dx.doi.org/10.1099/ijs.0.041434-0

[40] Teeling, H., Fuchs, B.M., Becher, D., Klockow, C., Gardebrecht, A., et al. (2012) Substrate-Controlled Succession of Marine Bacterioplankton Populations Induced by a Phytoplankton Bloom. Science, 336, 608-611. http://dx.doi.org/10.1126/science.1218344 
[41] Nedashkovskaya, O.I., Kim, S.B., Han, S.K., Snauwaert, C., Vancanneyt, M., et al. (2005). Winogradskyella thalassocola gen. nov., sp. nov., Winogradskyella epiphytica sp. nov. and Winogradskyella eximia sp. nov., Marine Bacteria of the Family Flavobacteriaceae. International Journal of Systematic and Evolutionary Microbiology, 55, 49-55. http://dx.doi.org/10.1099/ijs.0.63307-0

[42] Nedashkovskaya, O.I., Kukhlevskiy, A.D. and Zhukova, N.V. (2012) Winogradskyellaulvae sp. nov., an Epiphyte of a Pacific Seaweed, and Emended Descriptions of the Genus Winogradskyella and Winogradskyella thalassocola, Winogradskyella echinorum, Winogradskyella exilis and Winogradskyella eximia. International Journal of Systematic and Evolutionary Microbiology, 62, 1450-1456. http://dx.doi.org/10.1099/ijs.0.032219-0

[43] Bergey, D.H., Harrison, F.C., Breed, R.S., Hammer, B.W. and Huntoon, F.M (Editors) (1923) Bergey’s Manual of Determinative Bacteriology. Baltimore Williams \& Wilkins, Baltimore.

[44] Fu, Y., Keats, K.F., Rivkin, R.B. and Lang, A.S. (2013) Water Mass and Depth Determine the Distribution and Diversity of Rhodobacterales in an Arctic Marine System. FEMS Microbiology Ecology, 84, 564-576. http://dx.doi.org/10.1111/1574-6941.12085

[45] Dang, H., Li, T., Chen, M. and Huang, G. (2008) Cross-Ocean Distribution of Rhodobacterales Bacteria as Primary Surface Colonizers in Temperate Coastal Marine Waters. Applied and Environmental Microbiology, 74, 52-60. http://dx.doi.org/10.1128/AEM.01400-07

[46] Sorokin, D.Y. (1995) Sulfitobacter pontiacus gen. nov., sp. nov.-A New Heterotrophic Bacterium from the Black Sea, Specialized on Sulfite Oxidation. Mikrobiologiya, 64, 354-365. (English Translation: 295-305)

[47] Suzuki, M.T., Rappe, M.S., Haimberger, Z.W., Winfield, H., Adair, N., Strobel, J. and Giovannoni, S.J. (1997) Bacterial Diversity among Small-Subunit rRNA Gene Clones and Cellular Isolates from the Same Seawater Sample. Applied and Environmental Microbiology, 63, 983-989.

[48] Li, Z., Qu, Z., Zhang, X. and Zhang, X.H. (2012) Lentibacter algarum gen. nov., sp. nov., Isolated from Coastal Water during a Massive Green Algae Bloom. International Journal of Systematic and Evolutionary Microbiology, 62, 10421047. http://dx.doi.org/10.1099/ijs.0.029868-0

[49] Pujalte, M.J., Macia, M.C., Arahal, D.R., Ludwig, W., Schleifer, K.H. and Garay, E. (2005) Nereida ignava gen. nov., sp. nov., a Novel Aerobic Marine $\alpha$-Proteobacterium That Is Closely Related to Uncultured Prionitis (Alga) Gall Symbionts. International Journal of Systematic and Evolutionary Microbiology, 55, 631-636. http://dx.doi.org/10.1099/ijs.0.63442-0

[50] Giovannoni, S.J., Britschgi, T.B., Moyer, C.L. and Field, K.G. (1990) Genetic Diversity in Sargasso Sea Bacterioplankton. Nature, 345, 60-63. http://dx.doi.org/10.1038/345060a0

[51] Field, K.G., Gordon, D., Wright, T., Rappé, M., Urback, E., Vergin, K. and Giovannoni, S.J. (1997) Diversity and Depth-Specific Distribution of SAR11 Cluster rRNA Genes from Marine Planktonic Bacteria. Applied and Environmental Microbiology, 63, 63-70.

[52] Morris, R.M., Rappe, M.S., Connon, S.A., Vergin, K.L., Siebold, W.A., Carlson, C.A. and Giovannoni, S.J. (2002) SAR11 Clade Dominates Ocean Surface Bacterioplankton Communities. Nature, 420, 806-810. http://dx.doi.org/10.1038/nature01240

[53] Cury, J.C., Araujo, F.V., Coelho-Souza, S.A., Peixoto, R.S., Oliveira, J.A.L., Santos, H.F., Davila, A.M.R. and Rosado, A.S. (2011) Microbial Diversity of a Brazilian Coastal Region Influenced by an Upwelling System and Anthropogenic Activity. PLoS ONE, 6, e16553. http://dx.doi.org/10.1371/journal.pone.0016553

[54] Rodrigues, J.L.M., Pellizari, V.H., Mueller, R., Baek, K., Jesus, E., et al. (2012) Conversion of the Amazon Rainforest to Agriculture Results in Biotic Homogenization of Soil Bacterial Communities. Proceedings of the National Academy of Sciences of the United States of America, 110, 988-993. http://dx.doi.org/10.1073/pnas.1220608110

[55] Halliday, E., McLellan, S.L., Amaral-Zettler, L.A., Sogin, M.L. and Gast, R.J. (2014) Comparison of Bacterial Communities in Sands and Water at Beaches with Bacterial Water Quality Violations. PLoS ONE, 9, e90815 http://dx.doi.org/10.1371/journal.pone.0090815

[56] Fuhrman, J.A., Hewson, I., Schwalbach, M.S., Steele, J.A., Brown, M.V. and Naeem, S. (2006) Annually Reoccurring Bacterial Communities Are Predictable from Ocean Conditions. Proceedings of the National Academy of Sciences of the United States of America, 103, 13104-13109. http://dx.doi.org/10.1073/pnas.0602399103

[57] Gilbert, J.A., Field, D., Swift, P., Thomas, S., Cummings, D., et al. (2010) The Taxonomic and Functional Diversity of Microbes at a Temperate Coastal Site: A "Multi-Omic" Study of Seasonal and Diel Temporal Variation. PLoS ONE, 5, e15545. http://dx.doi.org/10.1371/journal.pone.0015545 


\section{Supplementary}

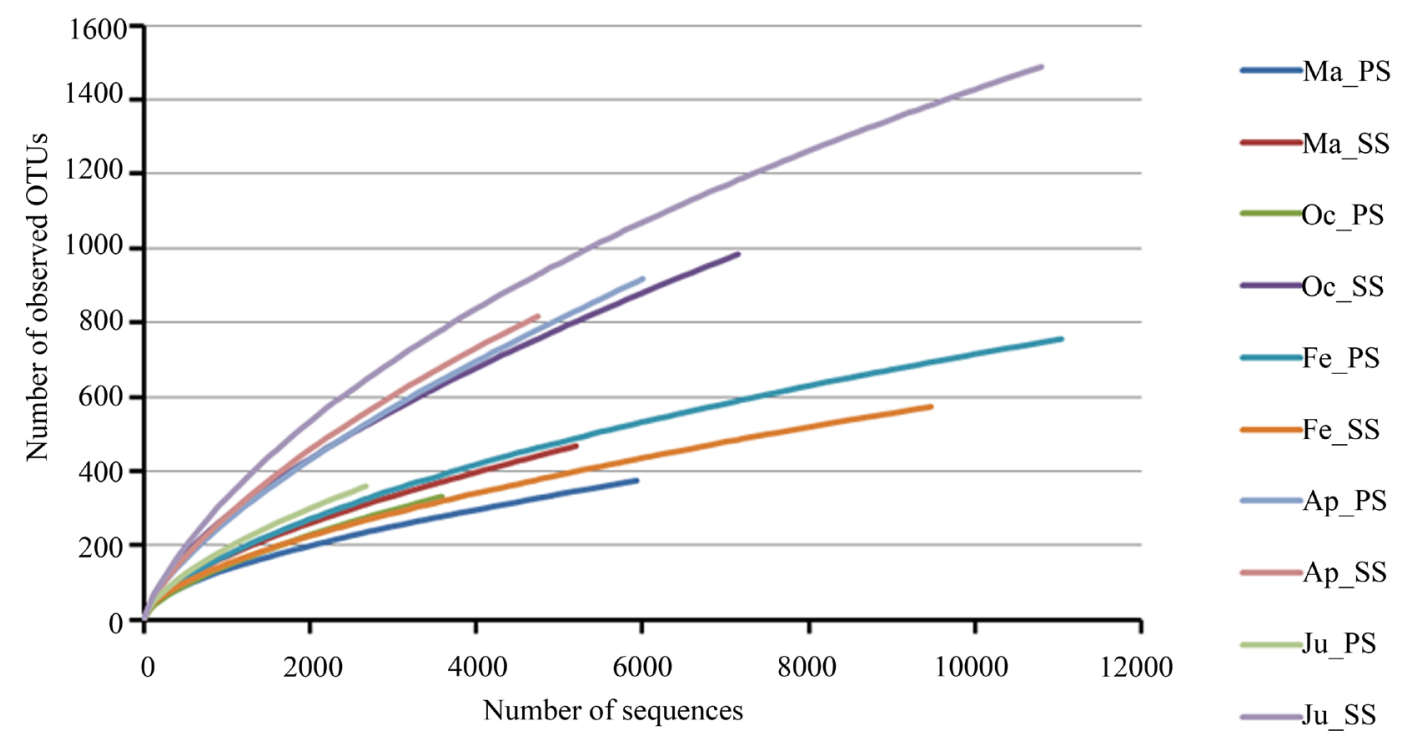

Figure 1A. Rarefaction curves of the samples from port side and sea side sampling stations indicating the number of observed OTUs at 0.03 cut-off levels. The first and the second part of the sample IDs' are expressing the sampling periods $(\mathrm{Ma}=$ March, $\mathrm{Oc}=$ October, $\mathrm{Fe}=$ February, $\mathrm{Ap}=$ April and $\mathrm{Ju}=\mathrm{July})$, and the sampling stations (PS = port side, $\mathrm{SS}=$ sea side), respectively.

\section{Submit or recommend next manuscript to SCIRP and we will provide best service for you:}

Accepting pre-submission inquiries through Email, Facebook, LinkedIn, Twitter, etc.

A wide selection of journals (inclusive of 9 subjects, more than 200 journals)

Providing 24-hour high-quality service

User-friendly online submission system

Fair and swift peer-review system

Efficient typesetting and proofreading procedure

Display of the result of downloads and visits, as well as the number of cited articles

Maximum dissemination of your research work

Submit your manuscript at: http://papersubmission.scirp.org/ 